\title{
Oxidation of Carbon Disulphide as the Sole Source of Energy for the Autotrophic Growth of Thiobacillus thioparus Strain TK-m
}

\author{
By NEIL A. SMITH AND DON P. KELLY* \\ Department of Biological Sciences, University of Warwick, Coventry CV4 7AL, UK
}

(Received 6 June 1988; revised 7 July 1988)

\begin{abstract}
The ability of micro-organisms to grow on carbon disulphide $\left(\mathrm{CS}_{2}\right)$ as a sole source of carbon and energy appears to be very limited: none was obtained from enrichment culture and eight Thiobacillus species could not use it. Thiobacillus thioparus strain TK-m could grow autotrophically on either $\mathrm{CS}_{2}$ or carbonyl sulphide (COS) as sole substrates. Growth yield on $\mathrm{CS}_{2}$ was $7.9 \pm 0.9 \mathrm{~g}$ cell-carbon $\left(\mathrm{mol} \mathrm{CS}_{2}\right)^{-1}$, and yields on $\mathrm{COS}$, thiosulphate or thiocyanate were in the range 5.6-6.1. COS was detected as an intermediate during growth on $\mathrm{CS}_{2}$, and there was quantitative conversion of the sulphur of $\mathrm{CS}_{2}$ to sulphate during growth. Aerobic oxidation of $\mathrm{CS}_{2}$ by suspensions of strain TK-m exhibited a $K_{\mathrm{s}}$ of $16.5 \mu \mathrm{M}$ and a $V_{\max }$ of $524 \mathrm{nmol} \mathrm{O} \mathrm{O}_{2}$ consumed $\mathrm{min}^{-1}$ (mg organism-protein) ${ }^{-1}$. When incubated anaerobically with $\mathrm{CS}_{2}$, strain TK-m sequentially produced $\mathrm{COS}$ and $\mathrm{H}_{2} \mathrm{~S}$. $\mathrm{CS}_{2}$ oxidation is proposed to proceed by its sequential hydrolytic cleavage to $\mathrm{COS}$ then $\mathrm{H}_{2} \mathrm{~S}$, with release of all the carbon as $\mathrm{CO}_{2}$, followed by oxidation of the sulphide to sulphate. This oxidation provides all the energy for growth, which is dependent on the autotrophic fixation of $\mathrm{CO}_{2}$, apparently by means of ribulose bisphosphate carboxylase.
\end{abstract}

\section{INTRODUCTION}

There is no significant literature on the microbial breakdown and metabolism of carbon disulphide $\left(\mathrm{CS}_{2}\right)$, notwithstanding the fact that it is a geochemically significant atmospheric trace gas with an atmospheric lifetime of $12 \mathrm{~d}$ (Khalil \& Rasmussen, 1984). Similarly, there is no information on the microbial oxidation of carbonyl sulphide (COS), which is a major intermediate in the oxidative metabolism of $\mathrm{CS}_{2}$ by rat liver microsomes (Chengelis \& Neal, 1987). These two gases occur in the atmosphere at concentrations of $0.07-0.56$ parts per billion (Bremner \& Steele, 1978), with COS being claimed as the most abundant sulphur gas in the atmosphere, with a lifetime of about 2 years (Khalil \& Rasmussen, 1984; Steudler \& Peterson, 1984). Other important sources are volcanic emissions of COS (Stoiber et al.. 1971), and the release of $\mathrm{CS}_{2}$ during its industrial use, which is significant because of the known hazard to human health presented by this compound (Sweetnam et al., 1987).

$\mathrm{CS}_{2}$ and $\mathrm{COS}$ are known to have a number of biogenic sources, including the degradation of cysteine, cystine, thiocyanates and other sulphur-containing compounds in soils, manures, decomposing plant material and the marine environment (Bremner \& Steele, 1978). They have also been shown to arise from the breakdown of pesticides and are themselves known to have harmful effects on some plants and fungi (Stotzky \& Schenk, 1976, Bremner \& Steele, 1978). CS $_{2}$ is also a natural product in the roots of Acacia, in which it may have a fungicidal role (Whitfield et al., 1981). It is also known to be an inhibitor of soil nitrification (Ashworth et al., 1977). The demonstration of metabolism of $\mathrm{CS}_{2}$ by micro-organisms appears at present to be limited to the observation that some methanogens can use it as a sulphur source for growth (Rajagopal \&

\footnotetext{
Abbreviations: $\mathrm{COS}$, carbonyl sulphide; $\mathrm{CS}_{2}$, carbon disulphide; CTAB, cetyltrimethylammonium bromide; MT, methanethiol; TOC, total organic carbon.
} 
Daniels, 1986), and a very brief report of its oxidation by Thiobacillus thiooxidans (Butler et al., 1969).

We now report some physiological and biochemical studies on the autotrophic, chemolithotrophic growth of Thiobacillus thioparus on $\mathrm{CS}_{2}$ and $\mathrm{COS}$ as sole growth substrates.

\section{METHODS}

Culture media. The mineral salts medium used for all batch and continuous cultures contained $\left(\mathrm{g}^{-1}\right): \mathbf{K H}_{2} \mathbf{P O}_{4}$, $2.0 ; \mathrm{K}_{2} \mathrm{HPO}_{4}, 2.0 ; \mathrm{NH}_{4} \mathrm{Cl}, 0.4 ; \mathrm{Na}_{2} \mathrm{CO}_{3}, 0.4 ; \mathrm{MgCl}_{2} .6 \mathrm{H}_{2} \mathrm{O}, 0.2 ; 3 \mathrm{ml}$ of vitamin mixture (Kanagawa et al., 1982) and $1 \mathrm{ml}$ of trace metal solution (Tuovinen \& Kelly, 1973); initial pH 7.1. Substrates were added as described below. Solid medium for plates and slopes was prepared by adding substrate and agar $(1.5 \%, \mathrm{w} / \mathrm{v})$ to the mineral salts medium. Thiobacillus thioparus strain TK-m was maintained on agar medium with 20 mM-sodium thiosulphate.

Growth in batch and continuous culture. Batch cultures $(50 \mathrm{ml})$ were grown in $250 \mathrm{ml}$ Quickfit flasks sealed with rubber Suba-seal stoppers. $\mathrm{CS}_{2}(2 \mathrm{mM}$, unless otherwise stated) was injected into the flasks using a Hamilton syringe. $C O S$ was added either as unsterilized gas or in solution in sterile distilled water. Thiosulphate (10-20 mM) and thiocyanate $(2-10 \mathrm{mM})$ were both sterilized in the mineral salts medium.

Radiolabelling experiments to measure the incorporation of ${ }^{14} \mathrm{C}$-labelled one-carbon compounds into cells growing on $2 \mathrm{~mm}-\mathrm{CS}_{2}$ or $\mathrm{COS}$ were done in sealed flasks as described above. Cultures $(50 \mathrm{ml})$ from which $\mathrm{Na}_{2} \mathrm{CO}_{3}$ had been omitted were supplemented with either $10 \mathrm{mM}-\mathrm{NaH}^{14} \mathrm{CO}_{3}, 10 \mathrm{mM}$-sodium $\left[{ }^{14} \mathrm{C}\right]$ formate or $1 \mathrm{mM}$ $\mathrm{H}^{14} \mathrm{CHO}$. Samples $(2 \mathrm{ml})$ were filtered through Whatman membrane filters $(0.2 \mu \mathrm{m}$ pore size), washed with water and counted in $10 \mathrm{ml}$ of LKB Optiphase Safe scintillant using a Beckman LS 7000 spectrometer.

Chemostat culture work was done in a 1 litre water-jacketed glass vessel (LH Engineering) containing $750 \mathrm{ml}$ of culture. Cultures were maintained at $30 \pm 1{ }^{\circ} \mathrm{C}$, stirred at 750 r.p.m. and aerated at $750 \mathrm{ml} \mathrm{min}{ }^{-1}$ with air. Culture $\mathrm{pH}$ was controlled at pH 6.8 by automatic titration with $0.5 \mathrm{M}-\mathrm{K}_{2} \mathrm{CO}_{3}$. Continuous cultures were established on $7.5-10.0 \mathrm{~mm}$-thiosulphate as the growth-limiting substrate, following inoculation $(20 \%, \mathrm{v} / \mathrm{v})$ with a batch culture grown on $20 \mathrm{~mm}$-thiosulphate and allowing $3 \mathrm{~d}$ further batch growth before commencing flow of medium. Some cultures were supplied with both thiosulphate and thiocyanate as dual growth-limiting substrates. Substrates were metered into the vessel separately from the mineral salts medium.

Respiration measurements. Oxygen uptake rates by suspensions of organisms were determined using a Tefloncoated Clark-type Rank oxygen electrode cell linked to a chart recorder. Suspensions $(2 \mathrm{ml})$ were taken either directly from a $10 \mathrm{~mm}$-thiosulphate-limited chemostat $\left(D 0.085 \mathrm{~h}^{-1}\right)$ or from a centrifuged, washed and resuspended suspension of organisms previously grown in batch culture on $\mathrm{CS}_{2}$. Substrate-dependent oxygen uptake was measured at $30^{\circ} \mathrm{C}$, the reaction being initiated by injection of substrate $(5-20 \mu l)$. Results are expressed as $\mathrm{nmol} \mathrm{O}_{2} \mathrm{~min}^{-1}$ (mg protein) ${ }^{-1}$, corrected for endogenous oxygen uptake.

Determination of transitory intermediates of $\mathrm{CS}_{2}$ metabolism. Gas chromatography/mass spectrometry (GC/MS) analyses were done using a Kratos mass spectrometer, model MS 25RFA, linked to a Carlo Erba gas chromatograph, model MFC 500, and fitted with a polar capillary column with length, internal diameter and film thickness of $25 \mathrm{~m}, 0.33 \mathrm{~mm}$ and $0.5 \mu \mathrm{m}$, respectively. The system used helium gas as carrier, with a flow rate of $1 \mathrm{ml} \mathrm{min}{ }^{-1}$. The temperature of the column was programmed at $50^{\circ} \mathrm{C}$ with increments of $20^{\circ} \mathrm{C} \mathrm{min}-1$ to a final temperature of $220^{\circ} \mathrm{C}$. The injection and detector temperatures were 240 and $200^{\circ} \mathrm{C}$, respectively. Identification of intermediates was by comparison of the mass spectra produced from the samples with those held on file by the computer, and by comparison with the mass spectra produced from authentic compounds. Samples for GC/MS analysis were prepared as follows. Batch cultures $(50 \mathrm{ml})$ on $2 \mathrm{mM}-\mathrm{CS}_{2}$ in sealed flasks were sampled $(1 \mathrm{ml})$ periodically throughout growth, and volatile intermediates extracted by vigorous shaking with chloroform $(2 \mathrm{ml})$ in sealed tubes. The organic phase was removed, transferred to a second tube and dried with a few crystals of $\mathrm{CaCl}_{2}$. This solution was taken for analysis using injection volumes of $0.5-1.0 \mu l$ with a split ratio of $100: 1$,

Gas chromatography (GC) analyses were done using a Pye Unicam Series 204 gas chromatograph linked to a Pye Unicam computing integrator (model PU 4810) and fitted with a Teflon column packed with acetone-washed Porapak QS. Column length and internal diameter were $1 \mathrm{~m}$ and $3 \mathrm{~mm}$, respectively. The system was equipped with a flame photometric detector incorporating a sulphur filter permitting light transmission at $349 \mathrm{~nm}$. The injection, column and detector temperatures were 200,100 and $250^{\circ} \mathrm{C}$, respectively. Gas flow rates for nitrogen (carrier gas), air and hydrogen were 40,50 and $70 \mathrm{ml} \mathrm{min}^{-1}$, respectively. Analyses were initiated by the injection of $100 \mu \mathrm{l}$ of headspace gas from cultures. Compounds were identified by comparison of retention times of peaks produced from samples with those obtained from authentic compounds. Under the conditions used, $\mathrm{H}_{2} \mathrm{~S}, \mathrm{COS}$ and $\mathrm{CS}_{2}$ had retention times of $0.81,1.1$ and $11.3 \mathrm{~min}$, respectively.

Time-dependent disappearance of $\mathrm{CS}_{2}$ and appearance of $\mathrm{H}_{2} \mathrm{~S}$ and $\mathrm{COS}$ by suspensions incubated aerobically or anaerobically at $30^{\circ} \mathrm{C}$ were determined as follows. Triplicate batch cultures $(100 \mathrm{ml}$ in $500 \mathrm{ml}$ stoppered flasks) were fed with five additions of $1 \mathrm{mM}-\mathrm{CS}_{2}$ over a period of $12 \mathrm{~d}$. The cultures were centrifuged at $21000 \mathrm{~g}$ for $15 \mathrm{~min}$, washed and the organisms $(15 \mathrm{mg}$ protein) resuspended in $10 \mathrm{ml}$ mineral salts medium. The suspension 
was divided into two equal portions in $23 \mathrm{ml}$ volume universal bottles sealed with rubber Suba-seals. Each was deoxygenated by bubbling with nitrogen and allowed to equilibrate at $30^{\circ} \mathrm{C}$. Reaction was initiated by injecting $10 \mu \mathrm{mol}$ of $\mathrm{CS}_{2} . \mathrm{CS}_{2}, \mathrm{COS}$ and $\mathrm{H}_{2} \mathrm{~S}$ were then monitored in the $18 \mathrm{ml}$ of headspace gas in the tubes over a period of 3-4 h. At this time total $\mathrm{H}_{2} \mathrm{~S}$ production was determined by acidifying the suspensions with $1 \mathrm{M}-\mathrm{HCl}$ to drive $\mathrm{H}_{2} \mathrm{~S}$ from solution and the headspace gas reanalysed. For comparison the experiment was also run under an air atmosphere.

Other analytical methods. Growth of cultures was monitored by measuring optical density $(1 \mathrm{~cm})$ at $440 \mathrm{~nm}$ in a Unicam SP 1700 UV/VIS spectrophotometer. Samples from chemostat cultures were used to prepare calibration curves relating optical density to biomass in terms of total organic carbon (TOC), protein or dry weight (mg $\mathbf{l}^{-1}$ ). Dry weights were determined by drying a centrifuged, washed and resuspended suspension of organisms in distilled water to constant weight at $105^{\circ} \mathrm{C}$. Pellets of organisms centrifuged from $4 \mathrm{ml}$ culture samples were assayed for TOC and protein: for TOC, aqueous suspensions of pellets were assayed using a Beckman Total Organic Carbon Analyzer, model 905B; for protein, organisms were dissolved in $0.5 \mathrm{M}-\mathrm{NaOH}(30 \mathrm{~min})$ and assayed by the Lowry procedure. Sulphate was determined by atomic absorption spectrophotometry: sulphate was precipitated with a standard solution of barium chloride and residual barium in the clear supernatant solution was measured at $553.6 \mathrm{~nm}$ (Varian Instrument Manual). Thiosulphate (and thiocyanate) were determined according to Kelly et al. (1969). Ribulose-1,5-bisphosphate carboxylase activity was assayed as described by Kelly \& Wood (1982), except that Triton X-100 was replaced by cetyltrimethylammonium bromide (CTAB; $0 \cdot 1 \%$, w/v) as the permeabilizing agent (Leadbeater et al., 1982).

Special chemicals. $\mathrm{CS}_{2}(99.9 \%)$ was obtained from Fisons or Aldrich; COS (96+\%) was from Aldrich; $\mathrm{Na}_{2}{ }^{14} \mathrm{CO}_{3}$, sodium $\left[{ }^{14} \mathrm{C}\right]$ formate and $\mathrm{H}^{14} \mathrm{CHO}$ were from Amersham. Chloroform used in the GC/MS analysis was of chromatographic grade from Fisons or Aldrich.

\section{RESULTS}

Growth of thiobacilli on $\mathrm{CS}_{2}$. No growth could be obtained on $2 \mathrm{mM}-\mathrm{CS}_{2}$ of $T$. neapolitanus (DSM 581), $T$. versutus (DSM 582), T. thioparus (DSM 505), T. acidophilus (DSM 700), T. thiooxidans (ATCC 8085), T. aquaesulis (DSM 4255, ATCC 43788) or T. tepidarius (DSM 3134, ATCC 43215). Slight growth and decrease in $\mathrm{pH}$ were seen with $T$. ferrooxidans (DSM 585), but this was not sustained on subculture. Growth was obtained using T. thioparus strain TK-m (Kanagawa et al., 1982; Kanagawa \& Kelly, 1986), which is also capable of growth on dimethyl sulphide and thiocyanate (Smith \& Kelly, 1988).

Growth rate and yield of $T$. thioparus strain $T K-m$ in batch culture on $C_{2}$ and $C O S$, and a comparison with yields on thiosulphate and thiocyanate. In batch culture on $2 \mathrm{mM}-\mathrm{CS}_{2}$ in sealed flasks, strain TK-m exhibited a doubling time of 30 to $40 \mathrm{~h}$ (i.e. a specific growth rate of about $0.02 \mathrm{~h}^{-1}$ ). Biomass production in these batch cultures was in the range $13.6-17.6 \mathrm{mg}$ bacterial organic carbon per litre of culture, indicating a yield of $7.9 \pm 0.9 \mathrm{~g}$ cell-carbon $\left(\mathrm{mol} \mathrm{CS}_{2}\right)^{-1}$ (from five estimations).

When strain TK-m was grown on COS under similar conditions, a yield of $6.1 \pm 0.8 \mathrm{~g}$ cellcarbon $(\mathrm{mol} \mathrm{COS})^{-1}$ was obtained.

A thiosulphate (7.5 mM)-limited chemostat culture, at a dilution rate of $0.085 \mathrm{~h}^{-1}$, gave a yield of $5.88 \mathrm{~g}$ cell-carbon (mol thiosulphate) ${ }^{-1}$. Supplementing the substrate feed of this culture with $5.2 \mathrm{~mm}$-thiocyanate resulted in complete oxidation of the thiocyanate (as well as of the thiosulphate) and an increase in the steady state biomass equivalent to a yield of $5.58 \mathrm{~g}$ cellcarbon (mol thiocyanate) ${ }^{-1}$.

From the oxygen requirements for the oxidation of each of these substrates $\left(2 \mathrm{~mol} \mathrm{~mol}^{-1}\right.$ for $\mathrm{COS}$, thiosulphate and thiocyanate; $4 \mathrm{~mol} \mathrm{~mol}^{-1}$ for $\mathrm{CS}_{2}$ ) the yields would be expected to be similar for the COS, thiosulphate and thiocyanate, as was found. The yield on $\mathrm{CS}_{2}$ would thus have been expected to fall in the range $11 \cdot 7 \pm 0.5$.

Stoichiometry and intermediates of $\mathrm{CS}_{2}$ metabolism. During growth on $\mathrm{CS}_{2}$, analysis by GC/MS of the chloroform-extractable volatiles from the culture medium showed a rapid initial formation of a compound indistinguishable from COS. This compound was detectable 


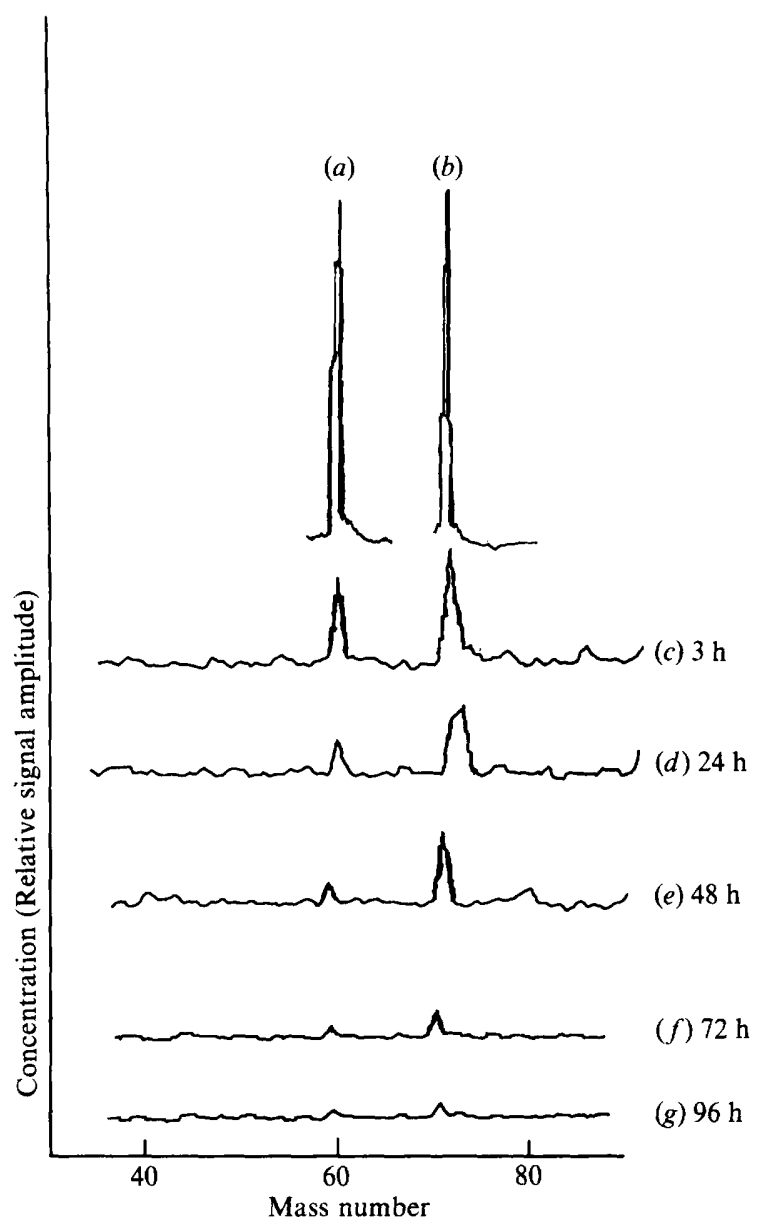

Fig. 1. Demonstration by GC/MS of the intermediate formation of COS during the growth of $T$. thioparis strain TK-m on $\mathrm{CS}_{2}(4 \mathrm{mM})$. Chloroform-extractable components of the culture were analysed as described in Methods. (a) Standard COS; (b) substrate $\mathrm{CS}_{2}$ standard; $(c-g)$ samples from the culture taken at the times indicated and analysed by GC/MS with chloroform as the internal reference compound.

throughout the culture period of $4 \mathrm{~d}$ but remained below the concentration of the residual $\mathrm{CS}_{2}$ (Fig. 1).

When a suspension $(5 \mathrm{ml})$ of $T$. thioparus $\mathrm{TK}-\mathrm{m}$ was incubated anaerobically under a headspace of $18 \mathrm{ml}$ nitrogen and given $10 \mu \mathrm{mol} \mathrm{CS}$, the $\mathrm{CS}_{2}$ disappeared quite rapidly from the headspace gas (Fig. 2). Its disappearance was paralleled by the formation of $\mathrm{COS}$ and $\mathrm{H}_{2} \mathrm{~S}$, with further $\mathrm{H}_{2} \mathrm{~S}$ accumulation apparently occurring at the expense of $\mathrm{COS}$ disappearance (Fig. 2). After 380 min anaerobic incubation, the experiment (Fig. 2) was terminated by acidification with $\mathrm{HCl}$ to release $\mathrm{H}_{2} \mathrm{~S}$ from solution. At that time, the amounts $(\mu \mathrm{mol})$ of $\mathrm{CS}_{2}, \mathrm{COS}$ and $\mathrm{H}_{2} \mathrm{~S}$ recovered in the headspace were $1.99,0.41$ and 15.4 respectively. This meant that of the $10 \mu \mathrm{mol}$ $\mathrm{CS}_{2}$ added, $8 \mu \mathrm{mol}$ were converted quantitatively to $\mathrm{COS}(2.6 \%)$ and $\mathrm{H}_{2} \mathrm{~S}(97 \cdot 4 \%)$. Under aerobic conditions, no such $\mathrm{COS}$ or $\mathrm{H}_{2} \mathrm{~S}$ accumulation was seen in a $200 \mathrm{~min}$ incubation, although traces of $\mathrm{H}_{2} \mathrm{~S}(1-6 \mathrm{nmol})$ were detected, and $49 \mathrm{nmol} \mathrm{COS}$ were seen after $20 \mathrm{~min}$, declining to an undetectable level by $63 \mathrm{~min}$. 


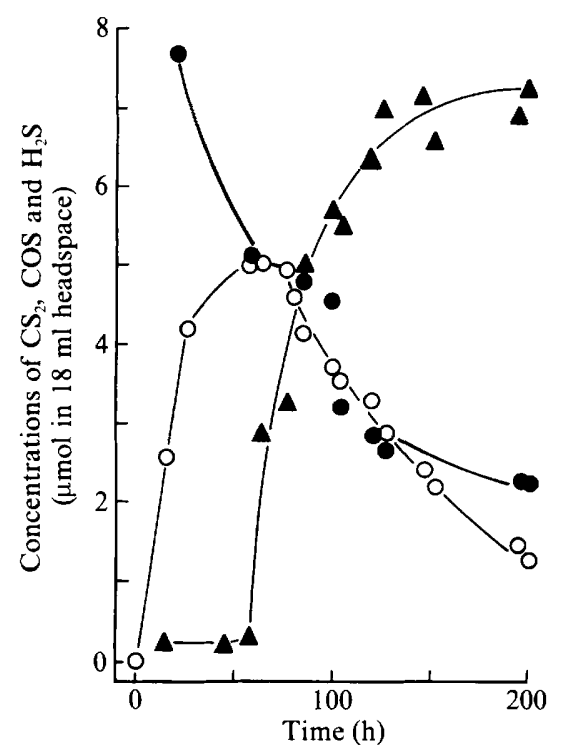

Fig. 2. Formation of $\operatorname{COS}(\mathrm{O})$ and $\mathrm{H}_{2} \mathrm{~S}(\Delta)$ from $\mathrm{CS}_{2}(\mathrm{O})$ during anaerobic incubation with $T$. thioparus strain TK-m. Suspensions were incubated under nitrogen with $10 \mu \mathrm{mol} \mathrm{CS}_{2}$ as described in Methods, and the headspace gas was analysed for $\mathrm{CS}_{2}, \mathrm{COS}$ and $\mathrm{H}_{2} \mathrm{~S}$.

Oxidation of $\mathrm{CS}_{2}$ and other sulphur compounds by T. thioparus strain $T K-m$. Using the oxygen electrode cell, the rate of oxidation of $\mathrm{CS}_{2}$ by $\mathrm{CS}_{2}$-grown organisms increased over a range of seven concentrations from $128 \mathrm{nmol} \mathrm{O}_{2}$ consumed min $^{-1}$ (mg cell-protein) ${ }^{-1}$ (at $5 \mu \mathrm{M}$ ) to 447 (at $50 \mu \mathrm{M}$ ), with no evidence of substrate inhibition over this concentration range. $K_{\mathrm{m}}$ and $V_{\max }$ were computed by the Lineweaver-Burk and Eadie-Hofstee procedures as $K_{\mathrm{m}}=16.0$ and $16.5 \mu \mathrm{M}$, and $V_{\max }=511$ and $524 \mathrm{nmol} \mathrm{O}_{2} \mathrm{~min}^{-1}(\mathrm{mg} \text { protein })^{-1}$, respectively. The Pearsons' correlation coefficients for the fit of the data (16 rate values) were 0.973 and 0.871 .

The stoichiometry of $\mathrm{CS}_{2}$ oxidation fell below the expected molar ratio of four $\mathrm{O}_{2}$ per $\mathrm{CS}_{2}$ oxidized: the best ratio was $1.5: 1.0$ at $25 \mu \mathrm{M}-\mathrm{CS}_{2}$, with a mean of $1.32 \pm 0.13 \mathrm{O}_{2}$ per $\mathrm{CS}_{2}$ for 5$50 \mu \mathrm{M}$. This probably indicated incomplete oxidation of sulphide, possibly resulting in sulphur accumulation.

For comparison, the oxidation of inorganic sulphur compounds by organisms taken from a thiosulphate-limited chemostat was assayed. Such organisms did not oxidize $\mathrm{CS}_{2}$. Sulphide was oxidized by organisms supplied with concentrations between 10 and $1000 \mu \mathrm{M}$. The oxidation rate increased from $106 \mathrm{nmol} \mathrm{O}_{2} \mathrm{~min}^{-1}$ (mg cell-protein) ${ }^{-1}$ at $10 \mu \mathrm{M}$ to 258 at $100 \mu \mathrm{M}$, but above this there was substrate inhibition with the rate at $1 \mathrm{~mm}$ falling to 130 . Thiosulphate oxidation showed complex kinetics, with a high affinity, low $V_{\max }$ phase below $50 \mu \mathrm{M}$ (resembling the kinetics seen with sulphide), and a low affinity, high $V_{\max }$ phase above $50 \mu \mathrm{M}$ (Table 1). Tetrathionate oxidation resembled the second phase of thiosulphate oxidation, with rate increasing from 144 at $25 \mu \mathrm{M}$ to 345 at $100 \mu \mathrm{M}$, and giving low $K_{\mathrm{m}}$ and high $V_{\max }$ values (Table 1).

Growth, sulphate production and assimilation of $\mathrm{CO}_{2}$ by $T$. thioparus strain $\mathrm{TK}-\mathrm{m}$ using $\mathrm{CS}_{2}$ or COS as sole substrate. When grown on either $\mathrm{CS}_{2}$ or $\mathrm{COS}$, virtually all the cell-carbon was seen to be derived from $\mathrm{CO}_{2}$ (Fig. 3). The decline in the amount of ${ }^{14} \mathrm{CO}_{2}$ fixed in the later stages of growth was attributed to dilution of the specific activity of the added $\mathrm{H}^{14} \mathrm{CO}_{3}$ by the $\mathrm{CO}_{2}$ produced from the oxidation of the substrates. In the early stages of growth, before this dilution became apparent, at least $90 \%$ of the increase in biomass was attributable to $\mathrm{CO}_{2}$ fixation. 

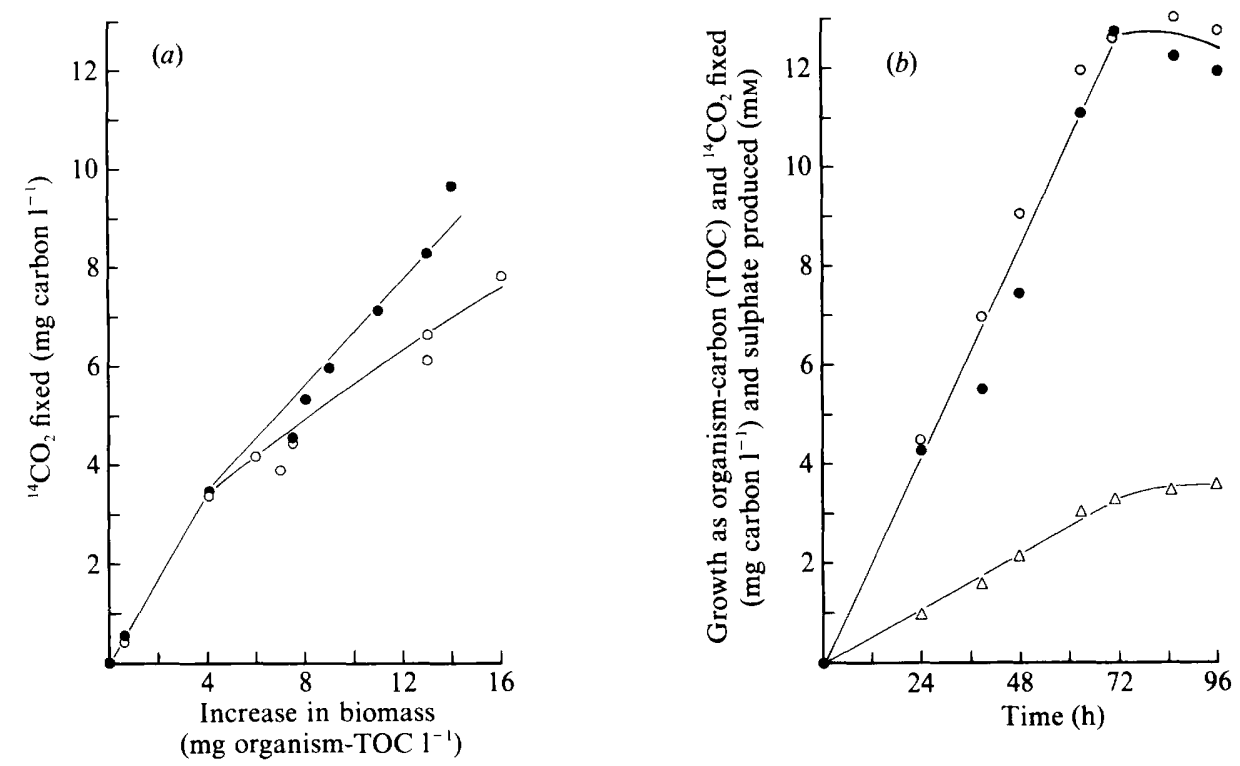

Fig. 3. Growth of $T$. thioparus strain TK-m on $\mathrm{CS}_{2}$ or $\mathrm{COS}$. $(a){ }^{14} \mathrm{CO}_{2}$ fixation during growth of cultures in sealed flasks, as described in Methods, on $2 \mathrm{mM}-\mathrm{CS}_{2}(\mathrm{O})$ or $2 \mathrm{mM}-\mathrm{COS}(\mathrm{O})$. Increase in cell-carbon as TOC and ${ }^{14} \mathrm{CO}_{2}$ fixation were measured over a $96 \mathrm{~h}$ growth period. Data are presented as a differential plot of the two measures of increase in cell-carbon. (b) Increase in biomass (as TOC, O), fixation of ${ }^{14} \mathrm{CO}_{2}(O)$ and formation of sulphate $(\triangle)$ by cultures growing on $2 \mathrm{mM}-\mathrm{CS}_{2}$. The data presented are mean values from duplicate cultures; deviation from the mean was $\pm 10 \%$. Data have been normalized to initial zero values by deducting the starting biomass and sulphate levels in the cultures ( $4.5 \mathrm{mg} \mathrm{TOC}^{-1}$ and $5.25 \mathrm{~mm}$, respectively).

Table 1. Kinetics of oxidation of inorganic sulphur compounds by T. thioparus strain TK-m

All substrates were tested using at least four concentrations over the ranges indicated. Pearsons' correlation coefficients for fit of the data to the computed lines were all in the range 0.934 to 0.999 .

$\begin{array}{lcccccc}\text { Substrate } & \begin{array}{c}\text { Concentration } \\ \text { range }(\mu \mathrm{M})\end{array} & \overbrace{\text { Lineweaver-Burk }}^{K_{\mathrm{m}}(\mu \mathrm{M})} & \text { Eadie-Hofstee } & \overbrace{\text { Lineweaver-Burk }}^{V_{\max }\left[\mathrm{nmol} \mathrm{O}_{2} \min ^{-1}(\mathrm{mg} \text { protein })^{-1}\right]} & \text { Eadie-Hofstee } \\ \text { Sulphide } & 10-100 & 18 \cdot 2 & 18 \cdot 5 & & 298 & 300 \\ \text { Thiosulphate } & 10-50 & 14 \cdot 8 & 13 \cdot 8 & 198 & 193 \\ \text { Tetrathionate } & 50-500 & 105 & 110 & & 464 & 477 \\ & 25-100 & 99 & 86 & & 721 & 661\end{array}$

Making simultaneous measurements of increase in absorbance, TOC in the organisms, ${ }^{14} \mathrm{CO}_{2}$ fixation and sulphate production showed these all to be proportionate during growth (Fig. $3 b$ ). During the complete oxidation of approximately $2 \mathrm{mM}-\mathrm{CS}_{2}$, about $13.9 \mathrm{mg}$ of newly synthesized cell-carbon was produced per litre (at least $90 \%$ from $\mathrm{CO}_{2}$ ), and $3.6 \mathrm{mM}$-sulphate was recovered. This represented $90 \%$ of the sulphur present in the $\mathrm{CS}_{2}$ supplied, and showed that complete oxidation of this substrate took place.

Incorporation of ${ }^{14} \mathrm{C}$-labelled formaldehyde during growth on $\mathrm{CS}_{2} . \mathrm{H}^{14} \mathrm{CHO}$ (added at $0.25 \mathrm{mM}$ ) was incorporated during growth on $\mathrm{CS}_{2}(2 \mathrm{mM})$ at a rate that was proportional to increase in biomass, but accounted for only about $5 \%$ of the cell-carbon fixed during growth. This would be consistent with its being assimilated only after oxidation to $\mathrm{CO}_{2}$. 
Ribulose-1,5-bisphosphate carboxylase in T. thioparus strain TK-m grown on $C S_{2}$. Low levels of this enzyme were detected using the permeabilized whole organisms method. No activity was found if Triton X-100 was used as the permeabilizing agent. Using CTAB-treated cells gave a specific activity of about $3 \mathrm{nmol} \mathrm{CO}_{2}$ fixed $\min ^{-1}$ (mg dry wt) ${ }^{-1}$, which was equivalent to about $5 \mathrm{nmol} \mathrm{m^{-1 }}$ (mg total organism protein $)^{-1}$. This can be compared with a specific activity, under similar assay conditions, of $45 \mathrm{nmol} \mathrm{min}^{-1}(\mathrm{mg} \text { dry wt) })^{-1}$ for organisms grown autotrophically in a thiosulphate-limited chemostat at a dilution rate of $0.08 \mathrm{~h}^{-1}$.

\section{DISCUSSION}

Our results serve both as the first detailed study of the microbial breakdown of $\mathrm{CS}_{2}$, and as a further demonstration of the metabolic versatility of $T$. thioparus strain TK-m. As well as its ability, as a typical Thiobacillus, to oxidize thiosulphate, tetrathionate and sulphide, it can grow on dimethyl sulphide as sole energy source (Kanagawa \& Kelly, 1986). We have now shown that it can also grow autotrophically on thiocyanate $(\mathrm{S}=\mathrm{C}=\mathrm{N}), \mathrm{CS}_{2}(\mathrm{~S}=\mathrm{C}=\mathrm{S})$ and $\mathrm{COS}(\mathrm{O}=\mathrm{C}=\mathrm{S})$, the metabolism of each of which requires the scission of a $\mathrm{S}=\mathrm{C}$ bond. The ability of the organism to attack $\mathrm{CS}_{2}$ under anaerobic conditions suggests that the first step of aerobic $\mathrm{CS}_{2}$ metabolism might be its hydrolytic cleavage to $\mathrm{COS}$ and $\mathrm{H}_{2} \mathrm{~S}$

$$
\mathrm{S}=\mathrm{C}=\mathrm{S}+\mathrm{H}_{2} \mathrm{O} \rightarrow \mathrm{O}=\mathrm{C}=\mathrm{S}+\mathrm{H}_{2} \mathrm{~S}
$$

The COS formed appears to undergo similar hydrolysis to $\mathrm{CO}_{2}$ and $\mathrm{H}_{2} \mathrm{~S}$.

$$
\mathrm{O}=\mathrm{C}=\mathrm{S}+\mathrm{H}_{2} \mathrm{O} \rightarrow \mathrm{CO}_{2}+\mathrm{H}_{2} \mathrm{~S}
$$

This scheme is in contrast to that proposed for the oxidative degradation of $\mathrm{CS}_{2}$ by rat liver, which is believed to be initiated by a NADPH-dependent monooxygenase, containing cytochrome P-450 (Chengelis \& Neal, 1987). Clearly a monooxygenase cannot be involved in the anaerobic production of $\mathrm{COS}$ and $\mathrm{H}_{2} \mathrm{~S}$ observed by us. The possibility that the normal aerobic metabolism of $\mathrm{CS}_{2}$ is initiated by an oxygenase, and that the anaerobic behaviour was artefactual, cannot, however, be unequivocally discounted.

The only source of energy available from the dissimilation of $\mathrm{CS}_{2}$ is clearly the oxidation to sulphate of the $\mathrm{H}_{2} \mathrm{~S}$ produced from it. $\mathrm{CS}_{2}$ and $\mathrm{COS}$ must therefore be regarded exclusively as chemolithotrophic substrates, in contrast to the methylated sulphides, which can be both chemolithotrophic and chemoorganotrophic energy sources. Growth yields on thiosulphate, thiocyanate and COS were similar, at $5 \cdot 6-6 \cdot 1 \mathrm{~g} \mathrm{cell}^{-c a r b o n} \mathrm{~mol}^{-1}$, indicating sulphur oxidation to be the only source of metabolic energy in each case. Yields on $\mathrm{CS}_{2}$ tended to be lower than expected given its equivalence to two sulphide molecules. This might be attributable in part to the difficulties of dispensing it with high accuracy into culture flasks, and partly a consequence of the very low growth rates observed. If, however, an $\mathrm{NAD}(\mathrm{P}) \mathrm{H}$-dependent monooxygenase is involved in the initial cleavage of $\mathrm{CS}_{2}$, the growth yield would be expected to be low, because $N A D(P)$ reduction driven by sulphide oxidation requires energy-dependent electron transport from cytochrome $b$ or $c$ (Kelly, 1982). This could consume at least one ATP and two of the 14 reducing equivalents available from $\mathrm{CS}_{2}$ oxidation (via a monooxygenase-dependent pathway) per NAD(P) reduced. If this occurred, one could predict that the yield on $\mathrm{CS}_{2}$ would only be 1.25 times greater than observed with COS. This would be a value of about $7 \cdot 6$, which compares closely with the observed yield of $7.9 \mathrm{~g}$ cell-carbon $(\mathrm{mol} \mathrm{CS})^{-1}$.

The mechanism of sulphide oxidation has not been further investigated, but the oxygen electrode data on $K_{\mathrm{m}}$ and $V_{\max }$ values for inorganic sulphur compounds, and the two-phase oxidation kinetics seen with thiosulphate, suggest that tetrathionate is an intermediate in thiosulphate oxidation and these might possibly be intermediates in sulphide oxidation.

Growth on $\mathrm{CS}_{2}$ was shown to be wholly autotrophic when assayed by ${ }^{14} \mathrm{CO}_{2}$ fixation, but only very low levels of ribulose bisphosphate carboxylase have so far been detected. This may reflect both the very low growth rate of the organism on $\mathrm{CS}_{2}$ and failure to assay under optimum conditions. To date, a sufficient bulk of $\mathrm{CS}_{2}$-grown organisms has not been obtained for the 
preparation of cell-free extracts. Formaldehyde was apparently only assimilated after oxidation to $\mathrm{CO}_{2}$, thereby discounting any alternative or unique $\mathrm{C}_{1}$-assimilatory pathway.

The ability to oxidize $\mathrm{CS}_{2}$ appears to be much more restricted among the bacteria studied to date than the capacity for oxidation of methylated sulphides or inorganic sulphur compounds. In that it can only be used as a chemolithotrophic energy source for autotrophic growth, it is perhaps not surprising that few organisms can oxidize it. The possibility that there exist in the natural environment specialist organisms better adapted to use it remains to be explored.

We thank the Natural Environment Research Council for support of this work.

\section{REFERENCES}

Ashworth, J., Briggs, G. G., Evans, A. A. \& MATULA, J. (1977). Inhibition of nitrification by nitrapyrin, carbon disulphide and trithiocarbonate. Journal of the Science of Food and Agriculture 28, 673683.

Bremner, J. M. \& Steele, C. G. (1978). Role of microorganisms in the atmospheric sulfur cycle. Advances in Microbial Ecology 2, 155-201.

Butler, R. G., Rothschild, B. \& Keller, J. R. (1969). Metabolism of carbon disulfide by Thiobacillus thiooxidans. Bacteriological Proceedings 64.

Chengelis, C. P. \& Neal, R. A. (1987). Oxidative metabolism of carbon disulfide by isolated rat liver hepatocytes and microsomes. Biochemical Pharmacology 36, 363-368.

Kanagawa, T. \& Kelly, D. P. (1986). Breakdown of dimethyl sulphide by mixed cultures and by Thiobacillus thioparus. FEMS Microbiology Letters 34, 13 19.

Kanagawa, T., Dazai, M. \& Fukuoka, S. (1982). Degradation of $O, O$-dimethyl phosphorodithioate by Thiobacillus thioparus TK-1 and Pseudomonas AK-2. Agricultural and Biological Chemistry 46, 2571-2578.

Kelly, D. P. (1982). Biochemistry of the chemolithotrophic oxidation of inorganic sulphur. Philosophical Transactions of the Royal Society B298, 499-528.

Kelly, D. P. \& WoOD, A. P. (1982). Autotrophic growth of Thiobacillus A2 on methanol. FEMS Microbiology Letters 15, 229-233.

Kelly, D. P., Chambers, L. A. \& Trudinger, P. A. (1969). Cyanolysis and spectrophotometric estimation of trithionate in mixture with thiosulfate and tetrathionate. Analytical Chemistry 41, 898-901.

Khalil, M. A. \& Rasmussen, R. A. (1984). Global sources, lifetimes and mass balances of carbonyl sulfide (COS) and carbon disulfide in the earth's atmosphere. Atmospheric Environment 18, 18051813.
Leadbeater, L., Siebert, K., Schobert, P. \& Bowien, B. (1982). Relationship between activities and protein levels of ribulosebisphosphate carboxylase and phosphoribulokinase in Alcaligenes faecalis. FEMS Microbiology Letters 14, 263-266.

Rajagopal, B. S. \& DaNiELS, L. (1986). Investigation of mercaptans, organic sulfides, and inorganic sulfur compounds as sulfur sources for the growth of methanogenic bacteria. Current Microbiology 14, 137-144.

SMITH, N. A. \& Kelly, D. P. (1988). Isolation and physiological characterization of autotrophic sulphur bacteria oxidizing dimethyl disulphide as sole source of energy. Journal of General Microbiology 134, 1407-1417.

Steudler, P. A. \& Peterson, B. I. (1984). Contribution of gaseous sulphur from salt marshes to the global sulphur cycle. Nature, London 311, 455-457.

Stolber, R. E., LeggetT, D. C., Jenkins, T. F., Murrmann, R. P. \& Rose, W. I. (1971). Organic compounds in volcanic gas from Santiaguito volcano, Guatemala. Bulletin of the Geological Society of America 82, 2299-2302.

STOTZKY, C. \& SchENK, S. (1976). Volatile organic compounds and microorganisms. CRC Critical Reviews in Microbiology 4, 353-371.

Sweetnam, P. M., TAYloR, S. W. C. \& Elwood, P. C. (1987). Exposure to carbon disulphide and ischaemic heart disease in a viscose rayon factory. British Journal of Industrial Medicine 44, 220-227.

Tuovinen, O. H. \& Kelly, D. P. (1973). Studies on the growth of Thiobacillus ferrooxidans. Archiv für Mikrobiologie 88, 285-298.

Whitfield, F. B., Shea, S. R., Gillen, K. J. \& Shaw, K. J. (1981). Volatile components from the roots of Acacia pulchella R. Br. and their effect on Phytophthora cinnamomi Rands. Australian Journal of Botany 29, 195-208. 